\title{
Transition of Future Energy System Infrastructure; through Power-to-Gas Pathways
}

\author{
Azadeh Maroufmashat and Michael Fowler* \\ Department of Chemical Engineering, University of Waterloo, 200 University Avenue West, \\ Waterloo, ON N2L 3G1, Canada; azadeh.mashat@gmail.com \\ * Correspondence: mfowler@uwaterloo.ca; Tel.: +1-519-888-4567 (ext. 33415)
}

Received: 1 June 2017; Accepted: 20 July 2017; Published: 26 July 2017

\begin{abstract}
Power-to-gas is a promising option for storing interment renewables, nuclear baseload power, and distributed energy and it is a novel concept for the transition to increased renewable content of current fuels with an ultimate goal of transition to a sustainable low-carbon future energy system that interconnects power, transportation sectors and thermal energy demand all together. The aim of this paper is to introduce different Power-to-gas "pathways", including Power to Hydrogen, Power to Natural Gas End-users, Power to Renewable Content in Petroleum Fuel, Power to Power, Seasonal Energy Storage to Electricity, Power to Zero Emission Transportation, Power to Seasonal Storage for Transportation, Power to Micro grid, Power to Renewable Natural Gas (RNG) to Pipeline ("Methanation"), and Power to Renewable Natural Gas (RNG) to Seasonal Storage. In order to compare the different pathways, the review of key technologies of Power-to-gas systems are studied and the qualitative efficiency and benefits of each pathway is investigated from the technical points of view. Moreover, different Power-to-gas pathways are discussed as an energy policy option that can be implemented to transition towards a lower carbon economy for Ontario's energy systems.
\end{abstract}

Keywords: power-to-gas; hydrogen economy; sustainable transportation; policy recommendation; Ontario; energy storage

\section{Introduction}

Power-to-gas (P2G) is the process of converting electricity into gaseous hydrogen fuel and one possible way is using the existing natural gas infrastructure for storage and distribution of the hydrogen enriched stream. As such, Power-to-gas bridges the electricity utility and natural gas grid to provide a fossil-free transportation fuel. This work will detail the applications of P2G and examine the efficiency of each application "pathway", and finally discuss how P2G can operate as a transition to future energy systems. This novel concept of the energy storage for future energy systems first emerged in Europe, specifically in Germany [1,2], where companies such as E.ON (North Rhine-Westphalia, Germany), EnBW (Karlsruhe, Germany) and GDF Suez (Courbevoie, France) are its pioneers [3]. The common aspect of P2G applications or "pathways" is the use of large scale electrolysers allowing for the convergence of utility and natural gas systems. Energy storage concepts such as "Power-to-gas" with hydrogen could significantly contribute to country's energy management needs by: enabling increased use of interment renewable sources of power, such as wind and solar [4-7], making efficient use of excess off-peak baseload nuclear power, and thus, improving life cycle emissions from power generation and transportation sectors [8,9]. Since P2G employs the current natural gas infrastructure, it provides an incremental transition to the greenhouse gas (GHG) emission free hydrogen economy [10]. More importantly this concept is for increasing the renewables and $\mathrm{CO}_{2}$-free, i.e., nuclear content into currently used fuels, specifically natural gas and liquid transportation ones. The low-cost and 
low-emissions off-peak surplus electricity is converted into hydrogen, which is used through different methods by going to the industrial applications or transportation [11]. If the hydrogen is not required immediately, it is stored for later use, including the potential for seasonal storage, which is especially interesting for power generation systems with a large amount of power [12]. Moreover, hydrogen can be injected into the natural gas network considering a maximum volume concentration [13]. Some advantages of $\mathrm{P} 2 \mathrm{G}$ are as follows [10,14-21]:

- It uses proven commercialized electrolyzer technology;

- It can be incrementally implemented to match changing infrastructure needs;

- It has proven ability to provide auxiliary electrical services;

- It provides highest energy storage density of currently available energy storage technologies;

- It can store and distribute energy in existing natural gas infrastructure including underground (salt caverns, depleted oil and gas wells, or existing natural gas storage sites) on a large scale and at lower cost, or as compressed gas or liquefied hydrogen in storage tanks;

- It is able to increase the renewable content of end-use petroleum fuels without the need to change vehicle technology or refueling infrastructure;

- It is able to store and distribute the energy into exiting natural gas infrastructure thus reducing the capital investment cost by leveraging existing infrastructure;

- It is able to store the energy for long periods, including from season to season;

- It can be coupled with increased biogas generation to develop renewable natural gas providing $\mathrm{CO}_{2}$ sequestration through methanation;

- It uses the hydrogen as a transportation fuel; and,

- It advances clean technology use in the industry sector creating economic development.

In addition to the strengths of P2G to be used for energy storage and as fuel for current transportation technology, the generation of hydrogen from clean electricity will help to usher in a new era of hydrogen vehicles and a "hydrogen economy" [22]. Many, if not most major vehicle manufactures have shifted their strategy to include hydrogen vehicles [23,24]. Hydrogen as an energy vector is generated from various energy resources such as fossil fuel, renewables as well as carbon-free nuclear power. This has led to the development of the "hydrogen economy" concept which concentrates on the study of the economic aspects associated with the production, distribution, and utilization of hydrogen in energy systems [25]. Hydrogen is a desirable long-term energy vector that can be stored and can be used to generate electricity; it can be produced from a diversified range of production pathways, it represents a secure energy supply, and when used in transportation applications it results in decreasing urban pollution and greenhouse gases (GHG) emissions [25]. From the electrical grid management point of view, the use of hydrogen as an energy carrier is appealing in the context of energy storage which impacts on competitive electricity markets, that is, enabling advantages to be taken of the significant price differences between peak and lower price hours (which may or may not necessarily coincide with peak and off-peak demand hours), and thus enables increased penetration of intermittent wind and solar energy, as well as GHG free nuclear power, so from a long-term viewpoint the 'hydrogen economy' represents a possible low-carbon economy.

\subsection{Importance of Natural Gas in Transition to Fossil-Free Economy}

There is an abundance of natural gas resources and natural gas distribution infrastructure, and the price is projected to be low for some time. Thus, electrons are clearly not the only way to move and store energy, and in many cases not the best way, as moving energy via natural gas pipeline is more efficient with less energy losses [26,27]. In the short term, natural gas provides an opportunity for immediate phase-out of coal, and to make immediate and significant advancements in transportation emissions, especially on fleet vehicles. Natural gas replacement of diesel fuel in Class 8 large fleet vehicles would significantly contribute to the reduction of air pollution [28,29]. Thus natural gas may not necessarily be part of the zero-carbon distant future, but is certainly part of the lower-carbon and 
lower-emission reality in the near term and a very useful transition technology with an abundance of infrastructure in place at this time. Few specific policies are needed to initiate the development of $\mathrm{P} 2 \mathrm{G}$ in the near term, besides strong vehicle emission regulations and carbon taxes which will drive this transition naturally, but certainly government incentives can accelerate this transition $[30,31]$. Note, as will be shown later one advantage of P2G is that it can be implemented incrementally, but each project implementation is a step towards a sustainable low-carbon economy, and any built additional infrastructure is effective, not only for the immediate application, but also for hydrogen vehicle refueling in the long-term. Most importantly, P2G can immediately enable the effective use of intermittent renewables and excess off-peak baseload nuclear power to increase the renewable energy content in current natural gas infrastructure or current vehicles.

\subsection{Importance of Hydrogen to World}

Hydrogen as a flexible and near-zero emission energy vector has a variety of applications in all energy sectors. Despite the fact that hydrogen is a chemical component that is plentiful in Nature, hydrogen can be produced using electricity. This hydrogen can be used as a fuel for electricity production again, however, this "pathway" application is still costly and has lower round trip efficiencies than battery storage. Currently, hydrogen is produced from different resources including, renewables and fossil fuels [32]. Electricity is another option for hydrogen production by means of electrolysis and water. Hydrogen itself has no carbon emissions if burned in a gas turbine or used in fuel cells. However, the process of hydrogen production from different energy sources may imply carbon emissions that should be considered in the life cycle assessment of the hydrogen production during the transition [33]. Hydrogen is a promising fuel for future road transport, thanks to fuel cell vehicles as a low-carbon option to internal combustion engine (ICE) vehicles. Furthermore, since the electricity utility infrastructure may not support the distribution capacity for the near-zero emission transportation by electric vehicles [34], both fuel cell vehicles and electric vehicles are needed and both are likely to command part of the market share in the long term. In the residential sector, micro combined heat and power systems can increase energy efficiency. In industry, the refining process and chemical industries can be decarbonized through the use of electrolytic hydrogen. The flexibility of the energy systems can be increased by the production of hydrogen from electricity and its storage, allowing for the high contribution of intermittent renewable energy. Moreover, hydrogen can be converted to different forms of final energy, namely, heat, power, as well as other types of fuels [35].

The keys to the energy systems based on a low-carbon footprint are flexibility and system integration. The integration of intermittent renewables and the variation of electricity demand and temporal fluctuations on daily and seasonal basis into the energy systems requires the operational flexibility of the power systems, which implies the need for the energy storage. Energy storage systems can be categorized by its capacity based on the input and output power and their discharge period. In line with project maintaining climate change to an increase of $2{ }^{\circ} \mathrm{C}$ scenarios, electricity storage systems accounts for up to $8 \%$ of the overall power capacity installed by 2050 [36]. Hydrogen-based technologies are suitable for broader range of storage applications including large-scale electricity storage applications at the megawatt scale, covering hourly to seasonal storage times.

\section{2. "Pathways" for Power-to-Gas Applications}

The key is that P2G offers different energy application "pathways" that can be implemented gradually and incrementally, making the most efficient use of the power generation mix both today and in the future. The P2G energy application "pathways" are as follows:

1. Power to Electrolyser (common to all pathways);

2. Power to Hydrogen to Natural Gas End-users via hydrogen enriched natural gas (HENG);

3. Power to Renewable Content in Petroleum Fuels;

4. Power to Power; 
5. Power-to-gas-Seasonal Energy Storage to Electricity;

6. Power to Zero Emission Transportation;

7. Power to Seasonal Storage for Transportation;

8. Power to Micro-grid;

9. Power to Renewable Natural Gas (RNG) to Pipeline ("Methanation"); and,

10. Power to Renewable Natural Gas (RNG) to Seasonal Storage.

As shown in Figure 1, the surplus power can be converted into hydrogen by means of an electrolyser [29,37]. This hydrogen can then be directly utilized or converted to low-carbon methane which requires an additional process and consecutively results in higher cost and lower energy conversion efficiency. Each process or energy conversion/storage technology entails losses. The energy losses are acceptable in cases that the surplus electricity cannot be utilized for another application or its production must be curtailed (e.g., shedding of wind power, or dumping heat at nuclear power plants which take place in Ontario at this time). This hydrogen or low-carbon methane can be injected to natural gas pipeline to be used for residential heat purposes or for micro-combined heat and power systems (CHP) or for large-scale gas turbine, which has a lower $\mathrm{CO}_{2}$ emissions compared to the current conventional natural gas [38]. Moreover, in addition to that, hydrogen or HENG can be utilized for the low-carbon transportation applications (e.g., either natural gas vehicles running on HENG or hydrogen fuel cell vehicles). The utilization of the hydrogen can be seasonal or daily usage.

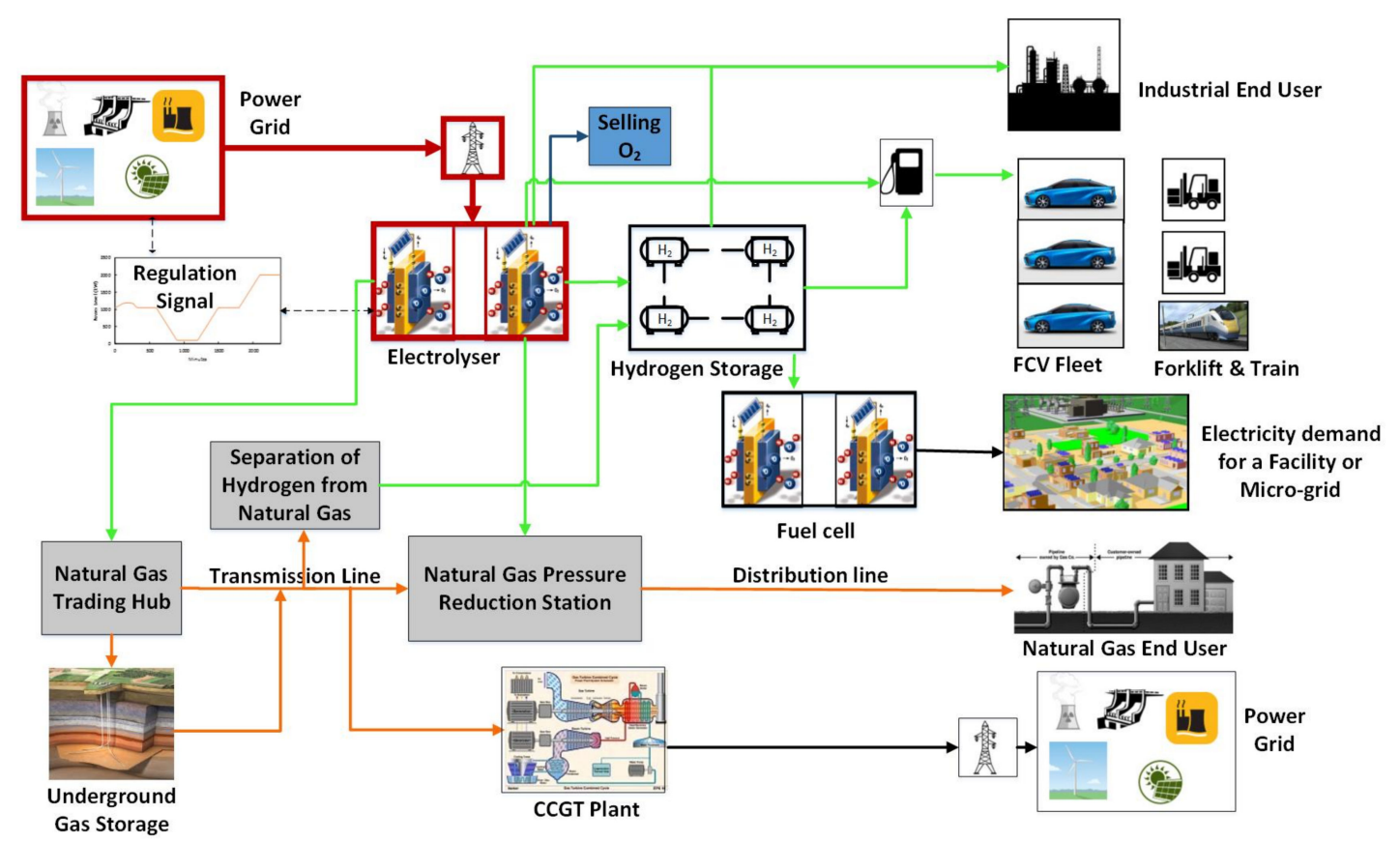

Figure 1. Schematic view of Power-to-gas.

\subsection{Power to Hydrogen to Natural Gas End-Users Pipeline Blending (HENG)}

Hydrogen generated from surplus power including renewable energies can be injected to natural gas pipelines to decarbonize natural gas via direct blending to make hydrogen-enriched natural gas (HENG). This concept demonstrates the feasibility of hydrogen blending to natural gas up to at most $10 \%$ without major effect on the existing natural gas infrastructure [39] or end-use equipment. This HENG has lower $\mathrm{CO}_{2}$ emissions compared to the natural gas, and can be used for different purposes such as heating, electricity generation, or as a fuel for the transportation sector, without any modification to the equipment of HENG systems. 
The electrolytic hydrogen which is produced by this method can be injected into the natural gas transportation or distribution pipelines, up to the certain limits. This limitation which is based on the fraction of the hydrogen allowable in the natural gas can be in the range of 5 to $20 \%$ for different applications [40-43]. Note that even with these concentrations, there is a need to build and install many electrolysers [31]. Moreover, hydrogen storage tanks are required as a buffer to balance the supply and demand of hydrogen. Since a part of grid electricity is from intermittent renewable energy, and due to the natural gas demand profile, there is need for energy storage systems. The optimum capacity of the storage systems is a challenging problem that is discussed in many related literatures. Literature results suggest that although considering the hydrogen storage systems' added complexity and more cost to the power-to-gas systems, they increase the performance of the whole system [14].

We note that society could achieve great benefits with the conversion of diesel Class 8 vehicles to natural gas. With P2G, these vehicles could also be fueled with the hydrogen enriched natural gas, without making any changes to the natural gas infrastructure thus increasing renewables and low-carbon contents in this fuel.

Key Technologies: Electrolyser, low-pressure compression, storage systems (optional), transmission and distribution pipelines

Qualitative Benefits: this pathway requires minimal incremental investment and can address the immediate need for energy storage. Moreover, it can reduce the need to shed or sell energy for loss, thus leading to lower Global Adjustment expenditures in Ontario.

\section{Technology Limitations and Outstanding Questions}

The allowable fraction of hydrogen in natural gas pipelines has several limitations. There are different key issues related to blending hydrogen into natural gas pipelines such as its effect on the end-user systems, safety and risk associated with blending hydrogen into natural gas, durability of pipeline materials, and leakage of hydrogen from pipelines.

Effect on the end-user systems: The effect of hydrogen blending into natural gas for end-user appliances namely, furnaces, boilers, and power generators depends on various factors including the natural gas composition, type of appliances or engine and their ages. Acceptable ranges for end-users fall between $5 \%$ and $20 \%$ of hydrogen and higher hydrogen blending may result in more cost $[39,44,45]$.

Compression stations and compressed natural gas (CNG) tanks have a limitation of up to $2 \%$ for hydrogen concentration, while dried, compressed blended hydrogen up to $20 \%$ in natural gas for dispensing to CNG vehicles are favorable due to higher performance [39]. Current installed gas turbines have a limitation up to $1 \%$, but hydrogen concentrations up to $5-15 \%$ can be attained with new adjustments and upgraded types. Hydrogen content in gas engines should not exceed $2 \%$, however, higher concentrations (up to $10 \%$ ) are possible with simple control system upgrades [36,42].

Safety and risk associated to blending hydrogen into natural gas: Safety and risk analysis are two important issues that should be considered when blending hydrogen into natural gas pipelines that depend on the hydrogen concentration, pipeline types and material, as well as failure mode conditions [40]. The main concern regarding the risk of blending hydrogen into natural gas pipelines is the possibility of ignition. The literature $[40,46,47]$ shows that natural gas systems enjoy a lower risk of severe accidents than large-scale power plants such as coal and nuclear, however, they pose a higher risk than renewable systems such as solar PV and wind [47]. Moreover, the risk associated with the transmission and distribution pipelines may be different, for instance, the distribution systems should be reassessed for the severity of the explosion, when near urban areas. Findings suggests that up to $20 \%$ of the hydrogen in a pipeline results in a minor increased ignition risk and in a case of natural gas leakage that results in explosion, there is a minor increase in the severity of the explosion [40]. Certainly in the initial stages of implementation (and for many years) concentrations in the natural gas system will be well below $2 \%$, and thus represent no significant risk increase over natural gas itself. 
Durability of pipeline materials: The material of pipelines may degrade faster when hydrogen is blended into natural gas, especially at a higher pressure and higher concentrations of hydrogen. This can be an issue for blending high concentrations of hydrogen into transmission pipelines, while at the distribution level, hydrogen is not a major concern for the steel pipelines. Many materials such as ductile iron, cast, as well as polyethylene which are used for the distribution pipeline are compatible with hydrogen [40]. Reference [39] suggested that fatigue and hydrogen embrittlement do not happen for concentrations up to a maximum of $10 \%$ hydrogen in natural gas for any type of material, thus once again in the initial stages of implementation no increase significant risks are anticipated.

Leakage of hydrogen from pipelines: Hydrogen is lighter than methane and can leak from pipeline fittings. The permeation rate of hydrogen is 4 to 5 times faster than methane and it can permeate more from walls rather than joints. However, the literature suggests that up to $20 \%$ hydrogen in natural gas is needed in order to have the same order of the leakage [40,43], so no increase significant risks are anticipated.

\subsection{Power to Increase Renewable Content in Petroleum Fuels}

The Renewable Fuel Standard was enacted in the U.S. several years ago to reduce the dependency on imported oil and promote the renewable fuel industry. Since then, oil companies started blending biofuels, typically ethanol, into the distributed gasoline in the range of $5-10 \%$. They also aim to reduce the carbon emissions released from cars during burning gasoline by increasing the oxygen content in the fuel $[48,49]$. However, ethanol has a lower energy output while its production can have an associated life cycle emissions and feedstocks are limited [50-52]. Therefore, the renewable electrolytic hydrogen can be recognized as a potential method for increasing the renewable energy within current transportation fuels without changing the quality or composition of the fuel itself. The life cycle emissions for traditional petroleum fuels, such as gasoline and diesel, start with crude extraction, crude transport, crude refining, petroleum fuels transportation and distribution, and finally vehicle consumption $[53,54]$. Each stage of the life cycle assessment contributes to the carbon intensity of gasoline and diesel. Unlike Steam Methane Reforming (SMR), hydrogen production from electrolysis has a significant low-carbon footprint when the electricity grid is powered by mostly renewables like in the province of Ontario [55,56]. The challenge for implementing electrolysis technology for the refining industry is the production cost compared to SMR as SMR normally has a lower production cost. Nevertheless, refiners will consider implementing electrolysis hydrogen, if provided environmental incentives from the government to meet the carbon intensity reduction target of gasoline as these regulations have been implemented in the U.S. and Europe [49,57].

Key Technologies: Electrolyser, low pressure compression, storage systems (optional).

Qualitative Benefits: This pathway reduces the carbon intensity of petroleum fuels through the use of power-to-gas for oil refining, increases the renewable content in petroleum fuels, and decarbonizes the transportation sector on the life-cycle basis without the need to convert current vehicle power training or refueling infrastructure. This 'pathway' is also complimentary with the addition of ethanol to gasoline, so the benefits of both methods for the introduction of renewable content can be applied at the same time.

\subsection{Power to Power}

Surplus power can be converted into hydrogen via electrolysers, pressurized and stored in storage systems, and then utilized when needed through fuel cells or hydrogen gas turbines. The main concern about this pathway is the additional technologies have a potential of increasing the energy losses and cost, as fuel cells will be required in the facility. Moreover, the round trip efficiency is lower than battery energy storage. Nevertheless, this pathway can be favorable in remote applications or the emergency situation with a blackout and could also provide extended back-up power applications. 
Key technologies: Electrolyser, low-pressure storage and compression, fuel cell.

Qualitative Benefits: To be competitive this pathway is beneficial for off-grid communities (e.g., mining sites [58,59], for smart grids and load leveling and as an aid to match energy supply and demand in power systems [60]. Thus this pathway would be a good option for storage of intermittent wind and solar energies and the proper use of excess baseload nuclear-based power in Ontario when integrated within a microgrid that includes a hydrogen refueling infrastructure or hydrogen industrial applications. Simple P2G can be used to provide power when and where it needed while being decoupled from the originating power generation profile which may not match the power demand profile.

\subsection{Power-to-Gas to Seasonal Energy Storage to Electricity}

Hydrogen produced from surplus electricity can be stored underground for a long term to be used when needed. Hydrogen storage along with natural gas storage can be utilized for electricity generation in large-scale natural gas-based power plants such as gas turbines or combined cycle power plants, or it can be separated from other gases to be consumed in fuel cells for electricity generation.

Key technologies: Electrolyser, low-pressure compression, underground storage, transmission pipelines, and natural gas-based power plants.

Qualitative Benefits: This pathway is an advantageous alternative for properly using wind energies as it is mostly available in spring and fall in Ontario (when electricity demand is low), for daily and weekly variation in energy demand, and it is useful for load leveling of baseload nuclear power in Ontario.

\subsection{Power to Hydrogen for Zero Emission Transportation}

Use as a transportation fuel is the other scenario for hydrogen. Hydrogen is compressed and stored at refueling stations at high pressure ranging from 300 to 700 bar for hydrogen vehicles or lift trucks. Note that $99.995 \%$ pure hydrogen is required for this application.

Hydrogen fuel cell vehicles can truly have zero emissions on a well-to-wheels basis when fueled with hydrogen that has been produced by electricity supplied from nuclear, hydro, wind or solar sources [61]. However, even when fuel cells use hydrogen made from natural gas, the GHG reductions are significantly less than for gasoline internal combustion engine (ICE) vehicles. The roadmap of hydrogen as a future transportation fuel relies on factors such as the fuel cell vehicle availability and the development of hydrogen refueling stations.

Key technologies: Electrolyser, low-pressure compression and storage, high-pressure compression for refueling station, hydrogen fuel cell vehicles (FVC) and forklifts.

Qualitative Benefits: This pathway is a promising opportunity for zero emission transportation systems in an urban area; it can integrate the electrical and transport energy sectors and there is no requirement to upgrade electricity distribution systems as required for battery electric vehicles, so it will be a mix of transportation technologies for future energy systems that consumers will have a preference to choose their type of vehicles. The use of hydrogen fuel cell vehicles (FCV) in urban areas will result in significant improvement of urban air quality, and the associated benefits in society's health outcomes. In both the short and long terms battery electric vehicles and fuel cell vehicle are complementary technologies with each technology being more desirable in different specific transportation applications.

\subsection{Power to Seasonal Storage for Transportation}

Hydrogen produced from surplus power via an electrolyser can be pressurized and stored in underground storage facilities such as salt caverns or depleted oil and gas reservoirs. In a case of transportation needs, the hydrogen can be separated from other gases via Pressure Swing Adsorption (PSA) and sent to the end users. This pathway is the same as "Power to Hydrogen for Zero Emission 
Transportation" with similar benefits, but an additional benefit is that the hydrogen is generated when intermittent renewable energy is plentiful, i.e., spring and fall in Ontario, and used year round in the transportation application. As such, this pathway is a long-term application where there is very high penetration of wind energy or high penetration of baseload nuclear, and large capacities of sessional energy storage is required.

Key technologies: Electrolyser, low-pressure compression, underground storage, hydrogen separation technologies, high-pressure compression for refueling station.

\subsection{Power to Microgrid}

Urban communities are struggling with technical issues such as electricity grid congestion at peak demand times, and underutilized excess power distribution infrastructure during off-peak hours due to the intermittency of renewable energies, such as solar power in urban areas and mismatch between supply and demand. P2G is an alternative for the energy storage in the form of hydrogen within micro grid, which can then be utilized for variety of microgrid energy requirements such as transportation demands, or to be converted into electricity for electricity use within the community [62]. It is also beneficial for remote off-grid communities and mining sites where larger energy storage capacities are needed [59,63].

Key technologies: Electrolyser, low-pressure energy storage and compression, fuel cells.

\subsection{Power to Renewable Natural Gas (RNG) to Pipeline ("Methanation")}

Hydrogen combined with carbon dioxide can used to create a stream of renewable natural gas which can mixed with the natural gas distribution system. This methane production from electricity has a higher energy loss and cost compared to the simple hydrogen production and blending. However, the clear benefit of renewable methane is that there are no limitations on the amount of blending into the natural gas distribution system and moreover, there is a carbon capture step that converts the carbon dioxide $\left(\mathrm{CO}_{2}\right)$ into renewable natural gas (RNG) [64]. This alternative can even be complimentary with the first pathway in which hydrogen can be injected to the natural gas pipeline up to the allowable limit and the remaining hydrogen can be converted to methane via methanation [65]. This process can occur inside a chemical reactor, biological reactor, or by natural methanation in underground storage. Since methanation is not a fully developed technology, some important factors should be taken in to account, namely, the purity of carbon dioxide, and the quality of synthesis methane. In a case of the production of low-quality synthetic methane, an additional gas cleaning process will be required. As example of power to RNG plants from surplus power and carbon capture have been demonstrated in a pre-commercial application in Germany $[1,18,66,67]$.

Key technologies: Electrolyser, low-pressure energy storage and compression, methanation reactor, gas clean-up, injection of renewable natural gas to natural gas pipelines.

Qualitative Benefits: Carbon sequestration from biogas production or industrial processes such as cement production.

\subsection{Power to Renewable Natural Gas (RNG) to Seasonal Storage}

Once renewable methane (RNG) is produced from surplus electricity it can be stored in underground storage and utilized when needed. Thus, methanation can be matched to an ongoing industrial or agricultural operation for carbon sequestration, and is not dependent on natural gas demand [68].

Key technologies: Electrolyser, low-pressure compression, methanation reactor, gas clean-up, underground storage, injection of RNG into natural gas pipelines. 


\section{Summary of Key Power-to-Gas Technologies}

\subsection{Electrolyser}

Electrolysers (Els) are the technologies at the core of P2G systems to convert electricity into fuel. There are different types of electrolysers, including alkaline and polymer electrolyte membrane (PEM), and solid oxide membrane (SO). The most mature and affordable ones, which have been commercial since 1920s [69], are the alkaline electrolysors [70], however, PEM electolysors, which are in early state commercialization have higher potential for cost reduction, durability, and efficiency improvement in the future [69]. Solid oxide electrolysors have the potential for even greater efficiency gain, however they operate at high temperature and are still in the research phase of development [36]. PEM electrolysers also have intrinsic benefits with regards to the higher current density and operational flexibility in terms of dynamic response and frequency regulation which are precondition for the future capital cost reduction. The operation flexibility is a key advantages of PEM electrolysers for the utility electricity grid when load should be immediately ramp up or down from the point of the normal operation [69,71], and the potential to provide auxiliary services would increase the technology's availability factor. Moreover, the performance of PEM electrolysers is maintained at elevated pressure unlike alkaline ones [72] which is a benefit for future P2G systems, because they can reduce the compression requirement for storage systems [69]. As of today, the rate of hydrogen production per stack and cell lifetime is amongst the limiting factors for PEM electrolysers [36,70], but they are expected to surpass alkaline technology in the near future.

The technical, operational, and economic information of the two most applicable electrolysers (alkaline and PEM electrolysers) are listed in the following table. This information has been gathered based on the different manufacturers' data and existing literature. The "current perspective" represents commercial or pre-commercial applications with a time frame of up to ten years, whereas long term planning is based on the future technologies with the improvement of their cost and performance, with a period of more than ten years ahead.

During the lifetime of PEM electrolysers, the stack needs to be refurbished every 60,000 to 65,000 $\mathrm{h}$ of operation. If a P2G plant were operated fully ( $24 \mathrm{~h}$ per day and 7 days per week), this would mean two stack refurbishments over the life of the plant. If the P2G plant were operated $16 \mathrm{~h}$ a day as a vision for a $\mathrm{H}_{2}$ fleet fueling application, there were be one stack refurbishment over the life of the plant. At future commercial production volumes, the estimated cost of a stack refurbishment would be about $35 \%$ of its capital cost for a turnkey electrolyser system [73,74].

The investment cost of alkaline electrolysers is less than that of the PEM electrolysers, which is around $\$ 1000$ per $\mathrm{kW}$ [72], however, this cost can be changed based on the specific size and thermodynamic condition $[36,75,76]$. The cost of PEM electrolysis is around $\$ 2000$ per $\mathrm{kW}$, which is estimated by E\&E consultants to be $\$ 1300$ per $\mathrm{kW}$ in future years [48]. The technical, operational, and economic data of alkaline and PEM electrolysers are summarized in Table 1. 
Table 1. Alkaline and Polymer Electrolyte Membrane (PEM) electrolyser technical, operational, and economic data.

\begin{tabular}{|c|c|c|c|c|c|}
\hline & & \multicolumn{2}{|c|}{ Alkaline Electrolyser } & \multicolumn{2}{|c|}{ Polymer Electrolyte Membrane (PEM) Electrolyser } \\
\hline \multicolumn{2}{|r|}{$\begin{array}{l}\text { Development stage } \\
\text { Electrolyte }\end{array}$} & \multicolumn{2}{|c|}{$\begin{array}{l}\text { Industrial since the 1920s [69] } \\
\text { Alkaline solution [77] }\end{array}$} & \multicolumn{2}{|c|}{$\begin{array}{c}\text { Early state commercial } \\
\text { perfluorosulfonic acid (PFSA) }\end{array}$} \\
\hline \multirow[t]{2}{*}{ Reactions } & \multirow[t]{2}{*}{$\begin{array}{l}\text { Anode } \\
\text { Cathode }\end{array}$} & \multicolumn{2}{|c|}{$\begin{array}{l}2 \mathrm{OH}^{-}=\frac{1}{2} \mathrm{O}_{2}+\mathrm{H}_{2} \mathrm{O}+2 \mathrm{e}^{-} \\
2 \mathrm{H}_{2} \mathrm{O}+2 \mathrm{e}^{-}=\mathrm{H}_{2}+2 \mathrm{OH}^{-}\end{array}$} & \multicolumn{2}{|c|}{$\begin{array}{c}\mathrm{H}_{2} \mathrm{O}=\frac{1}{2} \mathrm{O}_{2}+2 \mathrm{H}^{+}+2 \mathrm{e}^{-} \\
2 \mathrm{H}^{+}+2 \mathrm{e}^{-}=\mathrm{H}_{2}\end{array}$} \\
\hline & & Current Technology & Future Improvement & Current Technology & Future Improvement \\
\hline \multirow{11}{*}{$\begin{array}{c}\text { Technical } \\
\text { Information } \\
{[69,70,72]}\end{array}$} & Current density $\left(\mathrm{A} / \mathrm{cm}^{2}\right)[49]$ & $\begin{array}{l}0.2-0.4 \\
<0.4\end{array}$ & $<0.8$ & $\begin{array}{c}0.6-2 \\
<2\end{array}$ & $\begin{array}{c}1.5-3 \\
3.2\end{array}$ \\
\hline & Cell Temperature $\left({ }^{\circ} \mathrm{C}\right)$ & $60-80$ & $60-90$ & $50-80$ & $60-90$ \\
\hline & Cell voltage (V) & $\begin{array}{c}<30 \\
1.8-2.4\end{array}$ & $\begin{array}{c}60 \\
1.7-2.2\end{array}$ & $\begin{array}{c}<30 \\
1.8-2.2\end{array}$ & $\begin{array}{c}100 \\
1.6-1.8\end{array}$ \\
\hline & $\begin{array}{l}\text { System Efficiency based on Higher } \\
\text { heating value (HHV) (\%) }\end{array}$ & $62-82$ & $67-87$ & \multicolumn{2}{|r|}{$\begin{array}{l}1.0-1.0 \\
82-93\end{array}$} \\
\hline & System efficiency $\left(\mathrm{kWh} / \mathrm{N} \cdot \mathrm{m}^{3}\right)$ & $4.5-7.0$ & $4.3-5.7$ & \multicolumn{2}{|r|}{$4.1-4.8$} \\
\hline & Cell area $\left(\mathrm{m}^{2}\right)$ & 4 & 4 & \multicolumn{2}{|r|}{$<5$} \\
\hline & $\mathrm{H}_{2}$ production per stack $\left(\mathrm{N} \cdot \mathrm{m}^{3} \cdot \mathrm{h}^{-1}\right)$ & $<760-1000$ & \multirow{2}{*}{$\begin{array}{l}<1500 \\
90,000\end{array}$} & \multirow{2}{*}{\multicolumn{2}{|c|}{$\begin{array}{l}<250 \\
<60,000\end{array}$}} \\
\hline & Stack lifetime $(\mathrm{h})$ & 90,000 & & & \\
\hline & Permissible degradation rate $\left(\mu \mathrm{V} \cdot \mathrm{h}^{-1}\right)$ & $<3$ & $<3$ & \multicolumn{2}{|r|}{$<5$} \\
\hline & System life time (year) & $20-30$ & 30 & \multirow{2}{*}{\multicolumn{2}{|c|}{$\begin{array}{c}10-20 \\
>99.99 \%\end{array}$}} \\
\hline & Hydrogen purity & $99.90 \%$ & - & & \\
\hline \multirow{3}{*}{$\begin{array}{c}\text { Operation } \\
\text { Information } \\
{[69,72,73]}\end{array}$} & \multirow{3}{*}{$\begin{array}{c}\text { Dynamic response } \\
\text { Peak load } \\
\text { Lower partial load range (\%) } \\
\text { [Turn down] }\end{array}$} & Less than a minute & \multirow[b]{2}{*}{. } & \multicolumn{2}{|l|}{ within seconds } \\
\hline & & $100 \%$ & & $200 \%(30 \mathrm{~min})$ & - \\
\hline & & $20-40$ & $10-20$ & \multicolumn{2}{|r|}{$0-5$} \\
\hline \multicolumn{2}{|r|}{ Manufacturers [72,77] } & $\begin{array}{l}\text { AccaGen (CH), Acta (IT),A } \\
\text { Hydrogenics (CA), PERIC } \\
\text { Hydrogen Technologies (I } \\
\text { Uralkhimmasch (RU), Was }\end{array}$ & $\begin{array}{l}\text { S),ELT (DE), H2 Logic (DK), } \\
\text { (IT), Sagim (FR), Statoil } \\
\text { ne Energy Systems (US), } \\
\text { yse Hydrotechnik (DE) }\end{array}$ & $\begin{array}{l}\text { AccaGen (CH), CETH (FR) } \\
\text { Hydrogenics (CA), ITM Pc } \\
\text { (US), Statoil Hydrogen Tec }\end{array}$ & $\begin{array}{l}\text { S), h-tec (DE), Helion (FR), } \\
\text { Proton Energy Systems } \\
\text { (NO), Sylatech (DE) }\end{array}$ \\
\hline Economic & Investment Cost-CAD per KW & 850-1500 & 800 & $2000-3000$ & $800-1300$ \\
\hline Information & Operating Cost & $5-7 \%$ & - & $2-4 \%$ & - \\
\hline$[9,36,69,75,77]$ & Capacity Factor (\%) & 67 & 86 & $<86$ & 97 \\
\hline & Summary & $\begin{array}{l}\text { Lower degradation rate } / \mathrm{h} \\
\text { mature technology, and } \mathrm{hi}\end{array}$ & $\begin{array}{l}\text { jility as they are currently a } \\
\text { oduction rate high. }\end{array}$ & $\begin{array}{l}\text { Higher current density, hi } \\
\text { production rate per stack, } \\
\text { dynamic response and fre }\end{array}$ & $\begin{array}{l}\text { ency, lower hydrogen } \\
\text { operation in terms of } \\
\text { zulation [49] }\end{array}$ \\
\hline
\end{tabular}




\subsection{Hydrogen Storage and Compression}

One of the most challenges of P2G is the consideration of the hydrogen storage systems. Although one tries to keep the availability factor of the electrolyser at a high level, the cost (and correlated emissions factor) of the electricity grid will vary due to the intermittency of renewable energy in the power supply and unavoidable mismatch between energy supply and demand. The optimal hydrogen storage volume and the required type of storage are significantly dependent on the configuration and the operating parameters of the systems, as can be seen, the hydrogen storage systems in various pathways can be different [13].

There are different types of storage methods, including compressed gas either above or underground, liquid hydrogen as well as solid-metal hydrides. The most appropriate type of storage technology depends on the applications, where higher energy density is of great importance for mobile applications, while larger storage capacity and lower cost are required for stationary applications [15]. Consideration of safety and risk of storage systems are a perquisite for the location of any storage technology. Compressed storage tanks are the simplest storage systems, and despite the low storage density, higher pressure results in the higher density of storage and consequently higher costs $[78,79]$.

Low-pressure storage has larger capacities with pressures in the range of up to $30 \mathrm{bar}$, while the higher pressure storage vessels have a maximum operating pressure of 700 bar suitable for on-board storage in hydrogen-based refueling stations [36]. The main issue about hydrogen storage in liquid form is the boil-off losses, which results in instability in pressure and limited time of storage [80,81]. Storing hydrogen in cryo-compressed tanks can be a solution between pressurised and cryogenic systems [36]. Metal hydride technology is still in its infancy, but has the promise of higher volumetric densities for the storage, at the cost of weight. There is also an emerging technology of hydrogen storage via liquid organic hydrogen carriers (LOHCs). These LOHCs are hydrogenated for storage and dehydrogenated for use, and can make use of existing petroleum distribution infrastructure [82]. Based on different literature, pressurized hydrogen vessels and underground storage are the two most promising options for P2G. However, note that direct hydrogen injection into the natural gas distribution system can provide significant storage capacity for immediate needs without any required investment for additional infrastructure in the near future to medium-term.

Underground storage is another method for large scale, long term storage of gaseous hydrogen, which can be categorized into porous media storage, including depleted oil and gas fields and aquifers and cavern storage, including hard rocks and salt caverns [83]. Adequate capacity and containment, and the sufficient pressure are the primary requirements of underground storage systems that need to be satisfied, but there is an abundance of existing underground capacity, and more than enough for long-term seasonal energy storages requirements. A limiting criteria is the availability of proper geological formations for hydrogen storage. A report from the International Energy Agency (IEA) compares these underground storages from different points of view including safety, economy (capital and operational cost), as well as technical feasibility [32]. The results indicate that salt caverns are the best option for underground storage $[36,84]$, however, the storage cost of depleted oil and gas reservoirs seems to be lower based on a study by Lord et al. [85]. The compression pressure levels can vary in the range of 20 to 180 bar for underground storage [86]. Table 2 presents the technical, and economic data for hydrogen storage, compression and purification technologies.

\subsubsection{Hydrogen Refuelling Stations}

Hydrogen refuelling stations are an essential part of the fuel supply chain for fuel cell vehicles. However, each station can refuel a vehicle in 3 to $5 \mathrm{~min}$, so one station can service many vehicles as with current gasoline refuelling stations. The optimal sizing of hydrogen refueling stations is a challenging task due to the fact that the daily demand, the production method, and the form of hydrogen are changing over time [87]. The range of compression pressures for on-board fuel cell vehicles is around 350-700 bar. Hydrogen is provided at different pressure levels [high, medium, and low) at the refueling station. The higher the pressure of refueling stations, the more that must 
be invested in compressors. The capital cost of a 700 bar refueling station is about three times more than that of a 350 bar one. Delivering higher-pressure hydrogen to the refuelling station can lower its investment cost [36,87].

\subsubsection{Economic Analysis}

Lord et al. [85] listed the levelized capital cost of hydrogen for underground storage for different methods including salt caverns and depleted oil and gas reserves to be in the range of \$1.2-2.2 per $\mathrm{kg}$ hydrogen. However, the levelized capital cost of hydrogen storage is strongly dependent on the type of underground storage and the amount of storage. Compressor costs depend to the pressure ratio and their capacities; the cost range is reported in the range of $\$ 2000-17,000$ per kg hydrogen per hour $[80,88]$. A list of hydrogen storage system costs as well as hydrogen compressor cost can be found in [88] which are based on the information obtained from different literature and industry sources. Different literature reported various costs for gaseous hydrogen storage systems based on the storage system pressure and cost; the cost is within the range of \$400-1100 for low-pressure storage (up to 200 bar) and $\$ 1100-1700$ per kg hydrogen for high-pressure storage (up to 700 bar) [78,89]. For many hydrogen low-pressurized storage tanks based on SA516 Grade 70 carbon steel, the levelized capital cost of hydrogen storage capacity is $\$ 980$ per kilogram of hydrogen [87]. The technology for the compressors under 180 bar is mature, while that for compressors with higher pressure (700 bar) which are suitable for light duty vehicle refueling station have been recently commercialized [36]. Peng [15] summarized the costs of the several hydrogen purification technologies including PSA. The HENG fed to PSA typically contains $60-90 \%$ of hydrogen. Since the hydrogen recovery is relatively dependent on the feed composition, the efficiency which is the hydrogen recovery rate always remained above $82 \%$ for underground storage [30]. The range of PSA costs and its related efficiencies are shown in Table $3[15,30,88]$. As reported by National Renewable Energy Laboratory (NREL), the estimated cost of hydrogen extraction from PSA should be around $\$ 2$ to $\$ 8$ per kg considering the $20 \%$ concentration [39].

Table 2. Technical, and economic data for hydrogen storage, compression and purification technologies $[15,30,36,86,90,91]$.

\begin{tabular}{|c|c|c|c|c|c|c|}
\hline \multirow{2}{*}{ Technology } & \multirow{2}{*}{ Explanation } & \multicolumn{2}{|c|}{ Efficiency } & \multicolumn{2}{|c|}{ Cost (CAD Per kg or kg h ${ }^{-1}$ ) } & \multirow{2}{*}{ Lifetime } \\
\hline & & Current & Long Term & Current & Long Term & \\
\hline $\begin{array}{l}\text { Low pressure } \\
\text { hydrogen storage }\end{array}$ & $3-300 \mathrm{~kg}$ & $\begin{array}{c}\text { Almost } 100 \% \\
\text { (without compression) }\end{array}$ & - & $260-430$ & 15 & 20 \\
\hline \multirow[t]{2}{*}{$\begin{array}{l}\text { Compressor-for low } \\
\text { pressure storage }\end{array}$} & up to $180 \mathrm{bar}$ & $88-95 \%$ & $88-95 \%$ & $\sim 3000$ & 3000 & 20 \\
\hline & up to 350 bar & $89-91 \%$ & - & - & - & - \\
\hline $\begin{array}{l}\text { Compressor-for } \\
\text { refueling station }\end{array}$ & up to 700 bar & $80-91 \%$ & $80-91 \%$ & $8700-17,000$ & 13,000 & 20 \\
\hline $\begin{array}{l}\text { Injection to Pipeline } \\
\text { compression }\end{array}$ & $\begin{array}{l}\text { including } \\
\text { compression }\end{array}$ & $95 \%$ & $95 \%$ & - & - & - \\
\hline Underground storage & $\begin{array}{l}\text { GWh to TWh } \\
\text { (including } \\
\text { compression) }\end{array}$ & $90-95 \%$ & $95 \%$ & $300-350$ & 40 & 30 \\
\hline $\begin{array}{l}\text { Hydrogen } \\
\text { purification system }\end{array}$ & PSA & $80-95 \%$ & $85 \%$ & 4000 & 4000 & 20 \\
\hline
\end{tabular}

\subsection{Methanation}

Synthesis methane (SNG) can be produced by means of two types of methanation reactors including catalytic and biological reactors. The efficiency of both methanation processes are limited by the Sabatier reaction to a maximum of $80 \%$. The range of cost of catalytic methanation reactors are summarized in Table 3. As can be seen in this table, there is a large range of cost data for methanation reactors. 
Table 3. Costs of methanation processes.

\begin{tabular}{ccc}
\hline Reference & Explanation (Size) & Unit Capital Cost (\$ CAD Per kW RNG) \\
\hline Outotec GmbH [77] & for 5 MW & 560 \\
Outotec GmbH [77] & for 110 MW & 180 \\
Lehner et al. [92] & - & $400-700$ \\
Ausfelder et al. [93] & Forecast for 2050 & 800 \\
E\&E Consultants [76] & current & 2000 \\
Ueckerdt et al. [94] & future & 700 \\
SGC Report 2013 [76] & - & 1400 \\
\hline
\end{tabular}

\subsection{Fuel Cell}

Fuel cells are an electrochemical technology that converts chemical energy into electricity. They can operate with a wide range of fuels such as natural gas, and liquid fuels. Fuel cells are the key technology for using hydrogen efficiently. Moreover, if pure hydrogen is used for fuel cells, there will be no greenhouse gas emissions. There is a correlation between efficiency and power rate of fuel cell; the higher the efficiency, the lower the power output. The fuel cell market has been growing very fast in recent years; around $80 \%$ of the fuel cell applications are stationary, however, high capital cost and lifetime are two limiting factors for fuel cells. Hydrogen forklifts are a fully commercial application currently in use. Capital costs of fuel cells for stationary application are expected to drop to $\$ 1700$ to $\$ 2200$ per kW based on the data from U.S. Department of Energy [36].

\subsection{Other Technologies}

Gas turbines can respond rapidly to the variation of gas quality, when there is a hydrogen enriched natural gas. Assuming P2G directly blended in the pipeline and then delivered to a residential micro CHP system, the higher heating value efficiencies will be $\sim 87 \%$ which is the useful efficiency at maximum heating output [34,95]. Data regarding gas turbines, fuel cells and methanations as well as PEM fuel cells are presented in Table 4.

Table 4. Economics and efficiency of different technologies [15,86,96-101].

\begin{tabular}{cccccc}
\hline \multirow{2}{*}{ Technology } & \multirow{2}{*}{ Explanation } & \multicolumn{2}{c}{ Efficiency } & \multicolumn{2}{c}{ Cost (CAD Per kW Product) } \\
\cline { 2 - 5 } & Current & Long Term & Current & Long Term \\
\hline Methanation reactor & Catatic reactor & $77-80 \%$ & $80 \%$ & $1500-2000$ & $700-1000$ \\
\hline PEM fuel cell & $\begin{array}{c}\text { Stationary (0.5-400 } \mathrm{kW} \text { ) } \\
\text { Efficiency based on HHV }\end{array}$ & $32-49 \%$ & $45-50 \%$ & $3000-4000$ & $1000-2000$ \\
\hline Boiler/furnace & - & $88 \%$ & $92 \%$ & 100 & 100 \\
\hline $\begin{array}{c}\text { Micro combined heat and } \\
\text { power systems (CHP) }\end{array}$ & $\begin{array}{c}\text { Based on the total (electrical } \\
\text { and thermal efficiency) }\end{array}$ & $68-87 \%$ & $87 \%$ & $1100-2000$ & $1100-1850$ \\
\hline Large scale gas turbine & Electric Efficiency & $31 \%$ & $36 \%$ & $550-1700$ & $550-1700$ \\
\hline
\end{tabular}

\section{Efficiency Assessments of Power-to-Gas Pathways}

A schematic figure showing the different pathways is shown in Figure 2. The overall efficiencies of the different pathways are displayed in Table 5, along with the main components used in each application pathway. As can be seen in previous tables, there is a wide range of efficiencies for some technologies such as electrolysers and fuel cells, so the efficiency for each pathway is presented within a range as shown in the Table 5.

The results in Table 5 indicate that the overall efficiencies of the P2G pathways with hydrogen to the end users are higher than renewable natural gas production in methanation reactor, due to the additional energy conversion technologies that lead to more energy losses and lower efficiency. However, methanation does offer the potential for carbon capture [102]. 


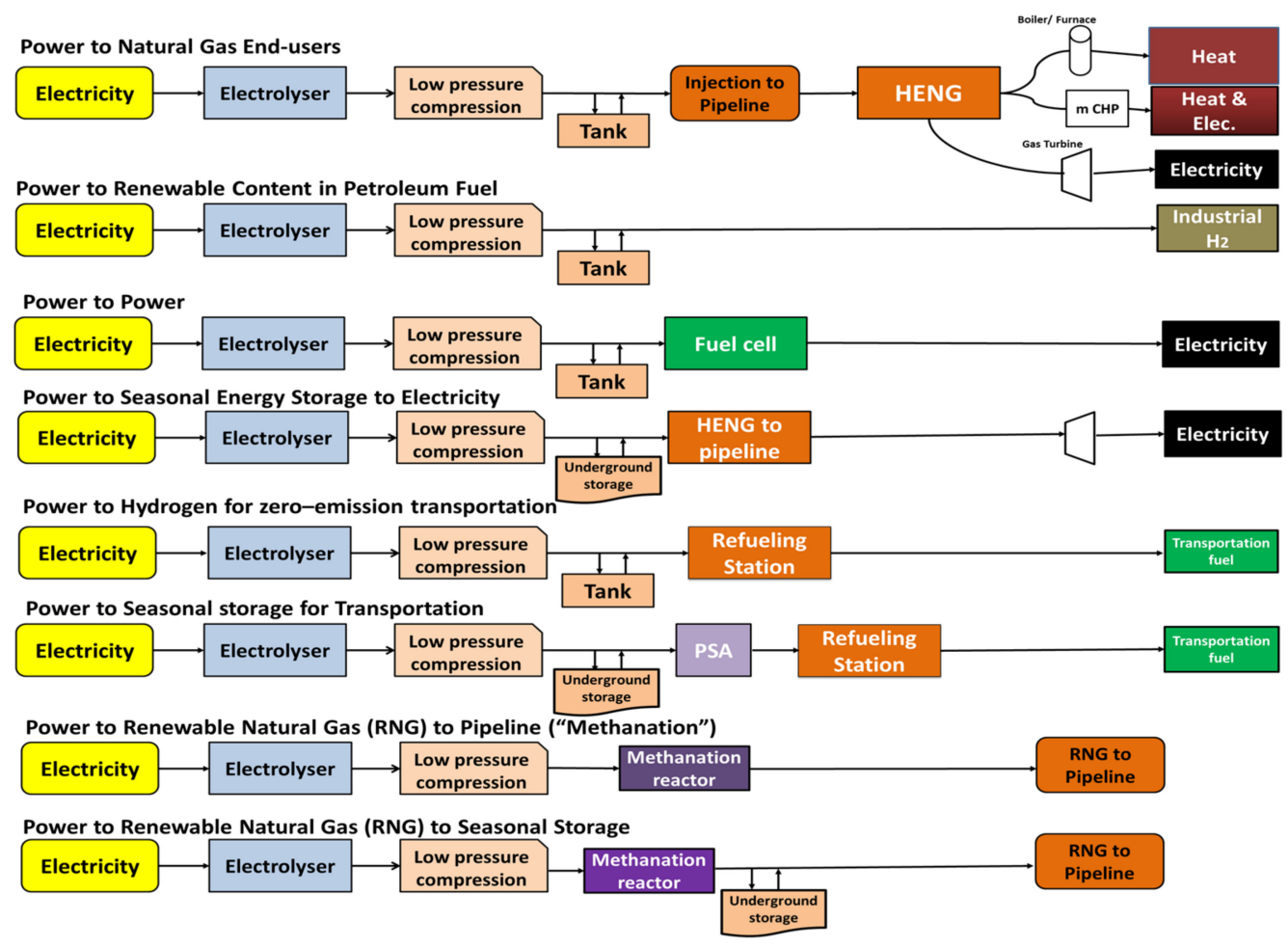

Figure 2. Different Power-to-gas pathways.

Table 5. Energy efficiency comparison of the different Power-to-gas (P2G) pathways.

\begin{tabular}{|c|c|c|c|}
\hline P2G Pathways & Technologies & Current & Long Term \\
\hline \multirow{4}{*}{ Power to Natural Gas End-users } & $\begin{array}{l}\text { Electrolyser, Low pressure hydrogen storage/compression, } \\
\text { Injection to pipeline }\end{array}$ & $59-83 \%$ & $64-86 \%$ \\
\hline & to heat for residential & $52-76 \%$ & $56-79 \%$ \\
\hline & to micro-CHP & $40-72 \%$ & $55-74 \%$ \\
\hline & to large scale gas turbines & $18-26 \%$ & $23-31 \%$ \\
\hline $\begin{array}{l}\text { Power to Renewable Content in } \\
\text { Petroleum Fuel }\end{array}$ & Electrolyser, Low pressure hydrogen storage/compression & $55-83 \%$ & $59-86 \%$ \\
\hline Power to Power & $\begin{array}{l}\text { Electrolyser, Low pressure hydrogen storage/compression, } \\
\text { fuel cell }\end{array}$ & $17-40 \%$ & $27-43 \%$ \\
\hline $\begin{array}{l}\text { Power to Seasonal Energy Storage } \\
\text { to Electricity }\end{array}$ & $\begin{array}{l}\text { Electrolyser, low-pressure compression, underground storage, } \\
\text { Transmission pipelines, Natural gas-based power plants }\end{array}$ & $16-24 \%$ & $22-29 \%$ \\
\hline $\begin{array}{l}\text { Power to Hydrogen for } \\
\text { zero-emission transportation }\end{array}$ & $\begin{array}{l}\text { Electrolyser, low-pressure compression and storage, } \\
\text { high-pressure compression for refueling station. }\end{array}$ & $50-79 \%$ & $54-82 \%$ \\
\hline $\begin{array}{l}\text { Power to Seasonal storage for } \\
\text { Transportation }\end{array}$ & $\begin{array}{l}\text { Electrolyser, low-pressure compression, underground storage, } \\
\text { hydrogen separation technologies, high-pressure compression }\end{array}$ & $36-68 \%$ & $43-66 \%$ \\
\hline $\begin{array}{l}\text { Power to Renewable Natural Gas } \\
\text { (RNG) to Pipeline } \\
\text { ("Methanation") }\end{array}$ & $\begin{array}{l}\text { Electrolyser, Low-pressure energy storage and compression, } \\
\text { Methanation reactor, Gas Clean-up, Injection of Renewable } \\
\text { Natural Gas to the Natural Gas Pipeline }\end{array}$ & $40-63 \%$ & $45-65 \%$ \\
\hline $\begin{array}{l}\text { Power to Renewable Natural Gas } \\
\text { (RNG) to Seasonal Storage }\end{array}$ & $\begin{array}{l}\text { Electrolyser, low-pressure compression, Methanation reactor, } \\
\text { Gas Clean-up, Underground storage, Injection of RNG to the } \\
\text { Natural Gas Pipeline }\end{array}$ & $34-60 \%$ & $43-58 \%$ \\
\hline
\end{tabular}

Using hydrogen for heating purposes for residential has an average efficiency of $63 \%$, while utilizing in micro combined heat and power systems (micro-CHP) results in 56\% efficiency. Moreover, direct utilization of hydrogen into natural gas pipeline has a higher efficiency compared to the production of electricity from hydrogen which has a round trip electricity efficiency around $25 \%$. The best option for electricity production from hydrogen is via fuel cells which is around 30\%, while the efficiency of hydrogen for transportation is about $64 \%$. Seasonal storage can lower the overall efficiency of P2G, but by no more than $10 \%$ lower. Power to renewable content in petroleum fuels has 
an average efficiency of $68 \%$ (current) and $72 \%$ (future), while a large SMR system has an efficiency in a range of over $70 \%$ [17].

Results indicate that in future years P2G can be competitive with conventional SMR from a technical point of view. However, the P2G cost is currently much higher than SMR, and thus its environmental impact should be considered to be competitive from economic points of view [96]. Improvements in technologies can increase the overall efficiency of P2G pathways in future years, which make them more economically feasible for implementation. The average energy efficiency of each P2G pathway is shown in Figure 3.

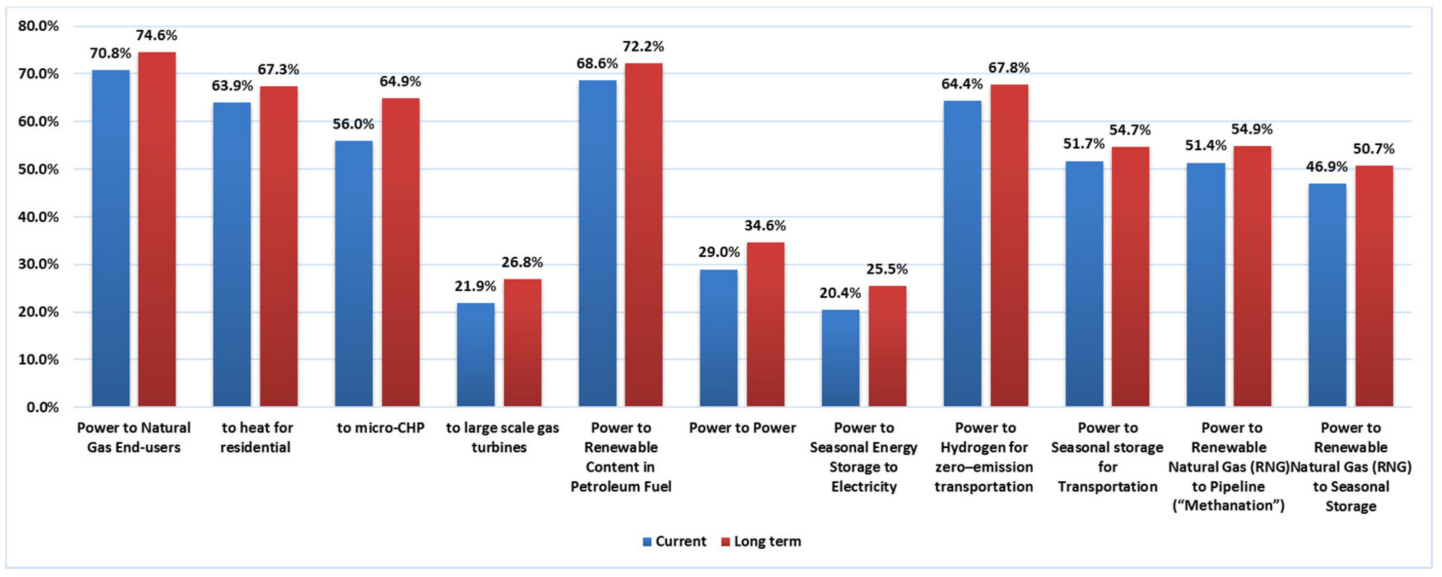

Figure 3. Average current and project energy efficiency of each Power-to-gas (P2G) pathway.

\section{Impact of Power-to-Gas on Ontario's Energy System}

There is a desire to envision a fossil-free economy in the future, but also not to severely impact the economy during the transition. A rapid transition to fossil-free is financially and economically infeasible. In this section, P2G will be presented as an energy policy option that can be used to transition towards a lower carbon economy.

Realizing the full potential of this paradigm shift would be facilitated by fully integrating Ontario's electrical distribution and natural gas distribution infrastructure. Natural gas is low-cost and plentiful in North America and will be a key component of the energy for the future, especially with decarbonizing energy production from coal and Class 8 diesel fuel transportation in the near term. Hydrogen production from electrolysis can provide the electricity system with many flexible operating benefits. As such natural gas system's distribution and storage assets could be leveraged, continue to use effectively and seasonally smooth hydrogen delivery for many industrial applications. As well, the natural gas distribution system can accommodate the blending in hydrogen, known as a P2G, that has the added benefit of "greening" natural gas, or increasing the low-carbon energy content. The use of natural gas systems would allow for a gradual increasing of hydrogen concentration in the distribution system, which results in emission reduction and efficient use of generation capacity in Ontario; consequently, a transition to higher $\mathrm{CO}_{2}$-free content in the natural gas stream. Electrolysis capacity can be added incrementally at operationally efficient intersection points of electricity generation or distribution systems as well as natural gas systems. Ultimately, as zero-emissions vehicles increase their market penetration, the use of the hydrogen generation assets for transportation applications as they come on line.

Power-to-gas represents an ideal transition technology concept, in which one can start immediately with a few electrolysers through a Power to Natural Gas End-user pathway, which results in efficient utilization of surplus nuclear and intermittent wind. Over the next 50 or 100 years, (depending on natural gas markets), the transition can be made incrementally in line with economic development to a completely low-carbon hydrogen economy. 
Energy storage concepts such as 'Power-to-gas' with hydrogen could immediately and significantly contribute to Ontario's energy management needs, makes use of the current natural gas infrastructure, improves emissions, and provides a transition to the hydrogen economy where major vehicles manufactures are commercializing fuel cell vehicles in the next 5 years. This does not require billions in borrowed funding and can be implemented incrementally starting today using made in Ontario technologies, e.g., with current two manufactures of electrolysers in Ontario. Other energy storage ideas may also provide some of the needed energy storage capacity depending on the application, and notability, Ontario is now running demonstrations of various storage options. Battery energy storage may provide daily energy arbitrage at a facility, but is not suitable for weekly or seasonal energy storage requirements. Thus P2G can be located near generation assets, e.g., wind farms and daily battery energy storage are complimentary energy storage technologies.

The transition could take place in different stage in a short-term and long-term planning. In short term, procurement of a small fleet of zero-emission vehicles should be done and the transition to the use of battery electric vehicles (BEVs) can be increased in off-peak hours with carbon-free electricity. However, in some locations current electricity distribution infrastructure may become saturated. To illustrate, a cluster of home that all use the same transform many overwhelm the duty cycle of the transformer, if all attempt to charge BEVs at the same time. Furthermore, Power to microgrid based on distributed energy technologies can be supported and this can foster the access to the limited hydrogen refueling stations, thus allowing complementary penetration of hydrogen vehicles. Moreover, natural gas fleets Class 8 vehicles including garage trucks and buses start to have increasing sales that all of these movements has a positive impact on Global Adjustment rate in Ontario as more electricity will use in the province for transportation applications. Electrolysis units can be located at refineries displacing SMR hydrogen and increasing the carbon reduced energy content of gasoline, which is equivalent to the reduction of 65,000 vehicles in Ontario, if all the SMR hydrogen is displaced [103]. In the longer-term, such as ten-year time horizon, as more hydrogen vehicles are sold, a commercial fuel distributor would like to build hydrogen refueling stations to increase the penetration of BEVs and FCVs. Of note, a fuel retailer whom is not part of large vertically integrated oil producer would be eager to generate and distribute hydrogen, as it increases the added value of their service. At the same time, renewable natural gas will start to make an impact to address animal waste from agricultural operations, further increasing the renewable content of the natural gas stream. Note, throughout this period no new energy distribution infrastructure is required as the existing natural gas system will be used. Also, as more 'Power-to-gas pathways' develop, there will have a positive impact on the avoidance of need for the expansion of local electrical utility infrastructure, which might have been required if transportation and heating demands were to switch to electricity. In addition to the implementation of more microgrids to support fleets, Power-to-Power can also offset the requirements for the development of electrical distribution infrastructure and facilitate more limited penetration of wind and urban solar. On top of that, large-scale underground hydrogen energy storage in existing natural gas facilities will start and the concentration of hydrogen blending in natural gas pipeline can be increased up to $2 \%$ without any modifications for natural gas end users. Power to transportation including rail will have been started after that. Commercial hydrogen locomotives have been demonstrated [104], so this technology will become commercially viable in say 10-20 years, and consequently, the required hydrogen production infrastructure will be available to meet this emerging demand. Longer term with more FCVs, as commercial companies will build more hydrogen refueling stations. Furthermore, the market penetration of BEVs and FCVs can thus both increase without any modifications and upgrade in the electricity distribution infrastructure. Hydrogen rail infrastructure does not require new rails or electrical distribution assets, which will also the refurbishment of existing or building new nuclear power plants to address increasing demand for energy, heating and transportation needs [105]. For heating purposes, P2G will increase the renewable content of the fuel, reducing the carbon emissions without any adjustments of current appliance in buildings. Note that with electrical generation servicing heating and transportation, there will be a 
requirement to increase significantly electricity production infrastructure, but $\mathrm{P} 2 \mathrm{G}$ will minimize this by more effectively using current generation assets and increasing their net availability. Transition to the low-carbon sustainable economy will happen gradually by implementing hydrogen infrastructure to supply energy demand for different sectors in the province.

The efficiencies shown in Figure 3 will allow policy developers to plan out energy transition plans. Considering Ontario's utility grid systems and natural gas, Power to hydrogen for natural gas end-users or for refineries or for transportation are amongst the most promising options of P2G to be implemented in Ontario, due to the higher efficiency and ready infrastructure. Moreover, the overall efficiencies of $P 2 G$ pathways with hydrogen to the end-users are higher than renewable natural gas production in methanation reactor, due to the additional energy conversion technologies that leads to the more energy losses and lower the efficiency, however, methanation does offer the potential for carbon capture. Thus, with minimal implementation of infrastructure, P2G can immediately address the need to store and use surplus renewable and nuclear energy in Ontario via a Power to Hydrogen to Natural Gas End-users via hydrogen enriched natural gas (HENG) pathway. Power to Renewable Content in Petroleum Fuels can immediate add in increasing the renewable content of current petroleum fuels with the need to change the current vehicle fleet. As society accelerates the transition to a sustainable low-carbon energy system, the developed electrolysis infrastructure can be implemented to service other energy application pathways. The policy recommendations given above are specifically for Ontario, however, one could generalize them for the whole country.

\section{Summary}

P2G should be considered as part of the policy and transition plan for future energy systems to respond to climate change. The abundance and low-cost of natural gas leads to the natural conclusion that realistically the natural gas distribution system and may be the application of natural gas, such a home heating will be a part of the energy mix for medium-term anyways. In this paper, different possible pathways of $\mathrm{P} 2 \mathrm{G}$ are presented in details and limitation of the associated technology readiness are discussed. In P2G, hydrogen generated from $\mathrm{CO}_{2}$ free sources of energy can be injected into the natural gas pipelines and used in current natural gas applications. The mixture of hydrogen and natural gas could also be distributed by pipeline to be separated at the end user for pure hydrogen applications, or fed to a combined cycle turbine to generate electricity that is sent to the grid, with the potential of emission reduction. The separated hydrogen can also be used to meet the demand of industrial hydrogen end-users or as a transportation fuel with the increasing penetrations of fuel cell vehicles. This paper has presented and discussed the associated efficiencies of the various application pathways. With this information, policy makers will be able to develop energy policy transition plans and strategies towards a low-carbon sustainable economy. The use of electrolytic hydrogen from intermittent renewable energy sources and baseload nuclear power will provide needed energy storage and clean emissions free transportation fuels for the energy requirement of the future. More importantly, through the gradual implementation of electrolysis capacity, current energy needs and issues can be immediately addressed, while developing infrastructure capacity for the future.

The technical and economic data of different P2G technologies are presented, and based on that the overall efficiency assessment of each pathways is presented. Results indicates that using P2G as hydrogen for heat purposes has an average efficiency of $63 \%$, while utilizing in micro-combined heat and power systems (micro-CHP) results in 56\% efficiency. Moreover, direct utilization of hydrogen into natural gas pipeline has a higher efficiency compared to the direct production of electricity from the hydrogen which is around $25 \%$. The best option for electricity production from hydrogen is via fuel cells which has round trip efficiency of around $30 \%$, while the efficiency of hydrogen for transportation is about $64 \%$. Power to renewable content in petroleum fuels has an average efficiency of $68 \%$ (current) and $72 \%$ (future), while a large Steam Methane Reforming (SMR) unit has an efficiency in a range of $70 \%$. Results indicate that in future years P2G can be competitive with SMR, from a technical point 
of view. Improvements in technologies can increase the overall efficiency of P2G pathways in future years by 2 to $5 \%$, which make them more feasible for implementation.

Acknowledgments: The authors would like to thank the financial support of National Science and Engineering Research Council (NSERC CRDPJ 451746-3), Ontario Center of Excellence (OCE MIS 20737), as well as our research partners Enbridge, Hydrogenics, Union Gas, GE, and Energy Technology \& Innovation Canada (ETIC).

Author Contributions: Azadeh Maroufmashat wrote the paper and carried out the entire literature review presented in this work. Michael Fowler provided key insights throughout the course of this work specially for Impact of Power-to-Gas on Ontario's Energy System.

Conflicts of Interest: The authors declare no conflict of interest.

\section{References}

1. Sterner, M. Bioenergy and Renewable Power Methane in Integrated 100\% Renewable Energy Systems: Limiting Global Warming by Transforming Energy Systems; Kassel University Press GmbH: Kassel, Germany, 2009.

2. Jentsch, M.; Trost, T.; Sterner, M. Optimal use of power-to-gas energy storage systems in an $85 \%$ renewable energy scenario. Energy Procedia 2014, 46, 254-261. [CrossRef]

3. German Energy Agency. Power-to-Gas: Partner. [Partner List for the German Power-to-Gas Strategy Platform]. Available online: http:/ / www.powertogas.info/ (accessed on 12 October 2016).

4. Gazey, R.; Salman, S.; Aklil-D'Halluin, D. A field application experience of integrating hydrogen technology with wind power in a remote island location. J. Power Sources 2006, 157, 841-847. [CrossRef]

5. Amirian, H.; Sayedin, F; Maroufmashat, A. Design and Modeling of an Integrated CHP System with Solar Hydrogen/Methane Fueled PEM Fuel Cell for Residential Applications. In Procedings of the ASME 2014 International Mechanical Engineering Congress and Exposition, Montreal, QC, Canada, 14-20 November 2014.

6. Grueger, F.; Möhrke, F.; Robinius, M.; Stolten, D. Early power to gas applications: Reducing wind farm forecast errors and providing secondary control reserve. Appl. Energy. 2017, 192, 551-562. [CrossRef]

7. Guandalini, G.; Robinius, M.; Grube, T.; Campanari, S.; Stolten, D. Long-term power-to-gas potential from wind and solar power: A country analysis for Italy. Int. J. Hydrogen Energy 2017, 42, 13389-133406. [CrossRef]

8. Specht, M.; Brellochs, J.; Frick, V.; Stürmer, B.; Zuberbühler, U.; Sterner, M.; Waldstein, G. Storage of renewable energy in the natural gas grid. Erdoel Erdgas Kohle 2010, 126, 342-346.

9. Schiebahn, S.; Grube, T.; Robinius, M.; Tietze, V.; Kumar, B.; Stolten, D. Power to gas: Technological overview, systems analysis and economic assessment for a case study in Germany. Int. J. Hydrogen Energy 2015, 40, 4285-4294. [CrossRef]

10. Walker, S.B.; Mukherjee, U.; Fowler, M.; Elkamel, A. Benchmarking and selection of Power-to-Gas utilizing electrolytic hydrogen as an energy storage alternative. Int. J. Hydrogen Energy 2016, 41, 7717-7731. [CrossRef]

11. Sharma, S.; Ghoshal, S.K. Hydrogen the future transportation fuel: From production to applications. Renew. Sustain. Energy Rev. 2015, 43, 1151-1158. [CrossRef]

12. Reuß, M.; Grube, T.; Robinius, M.; Preuster, P.; Wasserscheid, P.; Stolten, D. Seasonal storage and alternative carriers: A flexible hydrogen supply chain model. Appl. Energy 2017, 200, 290-302. [CrossRef]

13. Gahleitner, G. Hydrogen from renewable electricity: An international review of power-to-gas pilot plants for stationary applications. Int. J. Hydrogen Energy 2013, 38, 2039-2061. [CrossRef]

14. Mukherjee, U.; Elsholkami, M.; Walker, S.; Fowler, M.; Elkamel, A.; Hajimiragha, A. Optimal sizing of an electrolytic hydrogen production system using an existing natural gas infrastructure. Int. J. Hydrogen Energy 2015, 40, 9760-9772. [CrossRef]

15. Peng, D. Enabling Utility-Scale Electrical Energy Storage through Underground Hydrogen-Natural Gas Co-Storage. Master's Thesis, University of Waterloo, Waterloo, ON, Canada, 2013.

16. Qadrdan, M.; Abeysekera, M.; Chaudry, M.; Wu, J.; Jenkins, N. Role of power-to-gas in an integrated gas and electricity system in Great Britain. Int. J. Hydrogen Energy 2015, 40, 5763-5775. [CrossRef]

17. Mazloomi, K.; Gomes, C. Hydrogen as an energy carrier: Prospects and challenges. Renew. Sustain. Energy Rev. 2012, 16, 3024-3033. [CrossRef]

18. Wallbrecht, J. International Gas Union Triennium 2003-2006. Available online: http:/ /members.igu.org/ $\mathrm{html} /$ wgc2006/WOC2database/ (accessed on 12 October 2016).

19. Fogelson, J. California Plans for a Hydrogen Future. Forbes. Available online: http://www.forbes.com/ sites/jasonfogelson/2014/04/15/california-plans-for-a-hydrogen-future/ (accessed on 20 October 2016). 
20. De Santoli, L.; Basso, G.L.; Nastasi, B. The potential of hydrogen enriched natural gas deriving from power-to-gas option in building energy retrofitting. Energy Build. 2017, 149, 424-436. [CrossRef]

21. Mukherjee, U.; Maroufmashat, A.; Narayan, A.; Elkamel, A.; Fowler, M. A stochastic programming approach for the planning and operation of a power to gas energy hub with multiple energy recovery pathways. Energies 2017, 10, 868. [CrossRef]

22. Winkler-Goldstein, R.; Rastetter, A. Power to gas: The final breakthrough for the hydrogen economy? Green 2013, 3, 69-78. [CrossRef]

23. The 2017 Toyota Mirai Fuel Cell Vehicle. Available online: https://ssl.toyota.com/mirai/fcv.html (accessed on 24 July 2016).

24. Wilson, D. Power-to-gas: Utility-Scale Energy Storage. IESO. Available online: http://www.ieso.ca/ Documents / smart_grid/materials / 20120605/SGF-20120605-Hydrogenics.pdf (accessed on 20 January 2015).

25. Ball, M.; Weeda, M. The hydrogen economy-vision or reality? Int. J. Hydrogen Energy 2015, 40, 7903-7919. [CrossRef]

26. Interstate Natural Gas Pipeline Efficiency; INGAoA: Washington, DC, USA, 2010.

27. Colombo, S.; El Harrak, M.; Sartori, N. The Future of Natural Gas: Markets and Geopolitics; Lenthe/European Energy Review: Twente, The Netherlands, 2016.

28. Americas Commercial Transportation Research Co., LLC. The Future of Natural Gas Engines in Heavy Duty Trucks: The Diesel of Tomorrow? Available online: http://www.actresearch.net/wp-content/uploads/ 2013/04/ACT_NGP.pdf (accessed on 24 July 2017).

29. Paltsev, S.; Jacoby, H.D.; Reilly, J.M.; Ejaz, Q.J.; Morris, J.; O’Sullivan, F.; Rausch, S.; Winchester, N.; Kragha, O. The future of US natural gas production, use, and trade. Energy Policy 2011, 39, 5309-5321. [CrossRef]

30. Peng, D.D.; Fowler, M.; Elkamel, A.; Almansoori, A.; Walker, S.B. Enabling utility-scale electrical energy storage by a power-to-gas energy hub and underground storage of hydrogen and natural gas. J. Nat. Gas Sci. Eng. 2016, 35, 1180-1199. [CrossRef]

31. Mukherjee, U.; Walker, S.; Maroufmashat, A.; Fowler, M.; Elkamel, A. Development of a pricing mechanism for valuing ancillary, transportation and environmental services offered by a power to gas energy system. Energy 2017, 128, 447-462. [CrossRef]

32. Maroufmashat, A.; Fowler, M.; Khavas, S.S.; Elkamel, A.; Roshandel, R.; Hajimiragha, A. Mixed integer linear programing based approach for optimal planning and operation of a smart urban energy network to support the hydrogen economy. Int. J. Hydrogen Energy 2016, 41, 7700-7716. [CrossRef]

33. Marbán, G.; Valdés-Solís, T. Towards the hydrogen economy? Int. J. Hydrogen Energy 2007, 32, $1625-1637$. [CrossRef]

34. Accelerating the Deployment of Plug-In Electric Vehicles in Canada and Ontario BPLP, Plug'n Drive, Pollution Probe and University of Waterloo. Available online: http://www.brucepower.com/electricvehicle-report/ (accessed on 2 February 2017).

35. McDowall, W.; Eames, M. Forecasts, scenarios, visions, backcasts and roadmaps to the hydrogen economy: A review of the hydrogen futures literature. Energy Policy 2006, 34, 1236-1250. [CrossRef]

36. Körner, A.; Tam, C.; Bennett, S.; Gagné, J. Technology Roadmap-Hydrogen and Fuel Cells; International Energy Agency (IEA): Paris, France, 2015.

37. Ursua, A.; Gandia, L.M.; Sanchis, P. Hydrogen production from water electrolysis: Current status and future trends. Proc. IEEE 2012, 100, 410-426. [CrossRef]

38. Nastasi, B.; Basso, G.L. Hydrogen to link heat and electricity in the transition towards future smart energy systems. Energy 2016, 110, 5-22. [CrossRef]

39. Penev, M.; Melaina, M.; Bush, B.; Muratori, M.; Warner, E.; Chen, Y. Low-Carbon Natural Gas for Transportation: Well-to-Wheels Emissions and Potential Market Assessment in California; National Renewable Energy Laboratory (NREL): Golden, CO, USA, 2016.

40. Melaina, M.W.; Antonia, O.; Penev, M. Blending Hydrogen into Natural Gas Pipeline Networks: A Review of Key Issues; Contract No. DE-AC36-08GO28308; National Renewable Energy Laboratory (NREL): Golden, CO, USA, March 2013.

41. Judd, R.; Pinchbeck, D. Power to Gas Research Roadmap. Offering a Solution to the Energy Storage Problem; Gas for Energy, DIV Deutscher Industrieverlag GmbH: Munich, Germany, 2013.

42. Altfeld, K.; Pinchbeck, D. Admissible Hydrogen Concentrations in Natural Gas Systems; Gas for Energy, DIV Deutscher Industrieverlag GmbH: Munich, Germany, 2013. 
43. Dodds, P.E.; Demoullin, S. Conversion of the UK gas system to transport hydrogen. Int. J. Hydrogen Energy 2013, 38, 7189-7200. [CrossRef]

44. Florisson, O. Preparing for the Hydrogen Economy by Using the Existing Natural Gas System as a Catalyst; NaturalHy project Report SES6/CT/2004/502661; The European Commission's Sixth Framework Programme: Brussels, Belgium, 2010.

45. Dodds, P.E.; McDowall, W. The future of the UK gas network. Energy Policy 2013, 60, 305-316. [CrossRef]

46. Hirschberg, S.; Burgherr, P.; Spiekerman, G.; Dones, R. Severe accidents in the energy sector: Comparative perspective. J. Hazard. Mater. 2004, 111, 57-65. [CrossRef] [PubMed]

47. Burgherr, P.; Eckle, P.; Hirschberg, S. Comparative assessment of severe accident risks in the coal, oil and natural gas chains. Reliab. Eng. Syst. Saf. 2012, 105, 97-103. [CrossRef]

48. Farrell, A.; Sperling, D. A Low-Carbon Fuel Standard for California, Part 2: Policy Analysis. Institute of Transportation Studies; University of California: Berkeley, CA, USA, August 2007.

49. Ontario's Five Year Climate Change Action Plan 2016-2020; Government of Ontario: Toronto, ON, Canada, 2016.

50. Wang, M.; Han, J.; Dunn, J.B.; Cai, H.; Elgowainy, A. Well-to-wheels energy use and greenhouse gas emissions of ethanol from corn, sugarcane and cellulosic biomass for US use. Environ. Res. Lett. 2012, 7. [CrossRef]

51. Niven, R.K. Ethanol in gasoline: Environmental impacts and sustainability review article. Renew. Sustain. Energy Rev. 2005, 9, 535-555. [CrossRef]

52. Searchinger, T.; Heimlich, R.; Houghton, R.A.; Dong, F.; Elobeid, A.; Fabiosa, J.; Tokgoz, S.; Hayes, D.; $\mathrm{Yu}$, T.H. Use of US croplands for biofuels increases greenhouse gases through emissions from land-use change. Science 2008, 319, 1238-1240. [CrossRef] [PubMed]

53. Keesom, W.; Unnasch, S.; Moretta, J. Life Cycle Assessment Comparison of North American and Imported Crudes; Alberta Energy Research Institute: Chicago, IL, USA, 2009.

54. U.S. Environmental Protection Agency (EPA). Greenhouse Gas Emissions from a Typical Passenger Vehicle. Available online: https://www.epa.gov/greenvehicles/greenhouse-gas-emissions-typical-passengervehicle-0 (accessed on 25 July 2017).

55. Spath, P.L.; Mann, M.K. Life Cycle Assessment of Hydrogen Production Via Natural Gas Steam Reforming; National Renewable Energy Laboratory: Golden, CO, USA, 2000.

56. Collodi, G.; Wheeler, F. Hydrogen production via steam reforming with $\mathrm{CO}_{2}$ capture. Chem. Eng. Trans. 2010, 19, 37-42.

57. Transportation USEPAOo, Quality A. Renewable Fuel Standard Program: Draft Regulatory Impact Analysis; US Environmental Protection Agency: Washington, DC, USA, 2006.

58. The Underground (Hydrogen) Economy R. Available online: http://www.canadianminingjournal.com/ features/the-underground-hydrogen-economy/ (accessed on 20 February 2017).

59. Bétournay, M.C.; Rubeli, B. Hydrogen Power Application to Mining. In Proceedings of the Mining Diesel Emissions Council Conference, Toronto, ON, Canada, 2-4 October 2012.

60. Mukherjee, U.; Walker, S.; Fowler, M.; Elkamel, A. Power-to-gas in a demand-response market. Int. J. Environ. Stud. 2016, 73, 390-401. [CrossRef]

61. Hwang, J.J. Sustainability study of hydrogen pathways for fuel cell vehicle applications. Renew. Sustain. Energy Rev. 2013, 19, 220-229. [CrossRef]

62. Mukherjee, U.; Maroufmashat, A.; Ranisau, J.; Barbouti, M.; Trainor, A.; Juthani, N.; El-Shayeb, H.; Fowler, M. Techno-economic, environmental, and safety assessment of hydrogen powered community microgrids; case study in Canada. Int. J. Hydrogen Energy 2017, 42, 14333-14349. [CrossRef]

63. Zhang, X.; Chan, S.H.; Ho, H.K.; Tan, S.C.; Li, M.; Li, G.; Li, J.; Feng, Z. Towards a smart energy network: The roles of fuel/electrolysis cells and technological perspectives. Int. J. Hydrogen Energy 2015, 40, 6866-6919. [CrossRef]

64. Hoekman, S.K.; Broch, A.; Robbins, C.; Purcell, R. $\mathrm{CO}_{2}$ recycling by reaction with renewably-generated hydrogen. Int. J. Greenh. Gas Control 2010, 4, 44-50. [CrossRef]

65. Bailera, M.; Lisbona, P.; Romeo, L.M.; Espatolero, S. Power to Gas projects review: Lab, pilot and demo plants for storing renewable energy and $\mathrm{CO}_{2}$. Renew. Sustain. Energy Rev. 2017, 69, 292-312. [CrossRef]

66. Specht, M.; Jentsch, M.; Rieke, S.; Technologie, P.T.G. Erneuerbares Methan aus Ökostrom; ZSW Baden-Württemberg, Fraunhofer IWES, Solar Fuel GmbH: Stuttgart, Germany, 2012.

67. Newton, J. Power-to-Gas and Methanation e pathways to a 'Hydrogen Economy'. In Proceedings of the 14th Annual Apgtf Workshop, London, UK, 12-13 March 2014. 
68. Gutiérrez-Martín, F.; Rodríguez-Antón, L. Power-to-SNG technology for energy storage at large scales. Int. J. Hydrogen Energy 2016, 41, 19290-19303. [CrossRef]

69. Vanhoudt, W.; Barth, F.; Lanoix, J.; Neave, J.; Schmidt, P.; Weindorf, W.; Raksha, T.; Zerhusen, J.; Michalski, J. Power-to-Gas; Short Term and Long Term Opportunities to Leverage Synergies between the Electricity and Transport Sectors through Power-to-Hydrogen, Hinicio and LBST-Ludwig-Bölkow-Systemtechnik GmbH. Available online: http:/ / www.lbst.de/download/2016/Hinicio-LBST_2016_PtH2-study_Fondation-Tuck. pdf (accessed on 12 October 2016).

70. Carmo, M.; Fritz, D.L.; Mergel, J.; Stolten, D. A comprehensive review on PEM water electrolysis. Int. J. Hydrogen Energy 2013, 38, 4901-4934. [CrossRef]

71. Bodner, M.; Hofer, A.; Hacker, V. $\mathrm{H}_{2}$ generation from alkaline electrolyzer. Wiley Interdiscip. Rev. Energy Environ. 2015, 4, 365-381. [CrossRef]

72. Smolinka, T.; Günther, M.; Garche, J. NOW-Studie e Stand und Entwicklungspotenzial der Wasserelektrolyse zur Herstellung von Wasserstoff aus Regenerativen Energien, 2011. Available online: http:/ / www.now-gmbh.de/fileadmin/user_upload/RE_Publikationen_NEU_2013/Publikationen_ NIP/NOW-Studie-Wasserelektrolyse-2011.pdf (accessed on 12 October 2016).

73. Ainscough, C.; Peterson, D.; Miller, E. Hydrogen Production Cost from PEM Electrolysis; DOE Hydrogen and Fuel Cells Program Record; United States Department of Energy: Washington, DC, USA, 2014.

74. Harvey, R. Electrolyzer Specifications: Personal Communication with Hydrogenics; Hydrogenics Corporation: Mississauga, ON, Canada, 2016.

75. Consultant, E. Etude Portant sur l'Hydrogène et la Méthanation Comme Procédé de Valorisation de l'Électricité Excédentaire; E\&E Consultant, Hespul, Solagro: Cassel, France, 2014.

76. Benjaminsson, G.; Benjaminsson, J.; Rudberg, R.B. Power-to-Gas: A Technical Review; Svenskt Gastekniskt Center: Malmö, Sweden, 2013.

77. Götz, M.; Lefebvre, J.; Mörs, F.; Koch, A.M.; Graf, F.; Bajohr, S.; Reimert, R.; Kolb, T. Renewable Power-to-Gas: A technological and economic review. Renew. Energy 2016, 85, 1371-1390. [CrossRef]

78. Niaz, S.; Manzoor, T.; Pandith, A.H. Hydrogen storage: Materials, methods and perspectives. Renew. Sustain. Energy Rev. 2015, 50, 457-469. [CrossRef]

79. Wade, A. Costs of Storing and Transporting Hydrogen, (1998); National Renewable Energy Laboratory (NREL): Golden, CO, USA, 2014.

80. Roes, A.; Patel, M.K. Ex-ante environmental assessments of novel technologies-Improved caprolactam catalysis and hydrogen storage. J. Clean. Prod. 2011, 19, 1659-1667. [CrossRef]

81. Sherif, S.A.; Goswami, D.Y.; Stefanakos, E.L.; Steinfeld, A. Handbook of Hydrogen Energy; CRC Press: Boca Raton, FL, USA, 2014.

82. Teichmann, D.; Arlt, W.; Wasserscheid, P.; Freymann, R. A future energy supply based on Liquid Organic Hydrogen Carriers (LOHC). Energy Environ. Sci. 2011, 4, 2767-2773. [CrossRef]

83. Panfilov, M. 4.1 Underground hydrogen storage as an element of energy cycle. In Compendium of Hydrogen Energy: Hydrogen Storage, Distribution and Infrastructure; Elsevier: Berlin, Germany, 2016; Volume 91.

84. Landinger, H.; Bünger, U.; Raksha, T.; Simón, J.; Correa, L. Assessment of the Potential, the Actors and Relevant Business Cases for Large Scale And Seasonal Storage of Renewable Electricity by Hydrogen Underground Storage in Europe, HyUnder Company. Available online: http:/ / www.fch.europa.eu/project/ assessment-potential-actors-and-relevant-business-cases-large-scale-and-seasonal-storage-ren (accessed on 11 February 2017).

85. Lord, A.S.; Kobos, P.H.; Borns, D.J. Geologic storage of hydrogen: Scaling up to meet city transportation demands. Int. J. Hydrogen Energy 2014, 39, 15570-15582. [CrossRef]

86. Parks, G.; Boyd, R.; Cornish, J.; Remick, R. Hydrogen Station Compression, Storage, and Dispensing Technical Status and Costs: Systems Integration; National Renewable Energy Laboratory (NREL): Golden, CO, USA, 2014.

87. H2A Hydrogen Delivery Infrastructure Analysis Models and Conventional Pathway Options Analysis Results D-F-G, Interim Report; Nexant company: San Francisco, CA, USA, May 2008.

88. Weinert, J.X. A Near-Term Economic Analysis of Hydrogen Fueling Stations; Institute of Transportation Studies: UC Davis, Davis, CA, USA, 2005.

89. Simbeck, D.; Chang, E. Hydrogen Supply: Cost Estimate for Hydrogen Pathways—Scoping Analysis; National Renewable Energy Laboratory (NREL): Golden, CO, USA, 2002. 
90. Steward, D.M. Scenario Development and Analysis of Hydrogen as a Large-Scale Energy Storage Medium; National Renewable Energy Laboratory (NREL): Golden, CO, USA, 2009.

91. Myers, D.B.; Ariff, G.D.; James, B.D.; Lettow, J.S.; Thomas, C.; Kuhn, R.C. Cost and Performance Comparison of Stationary Hydrogen Fueling Appliances; The Hydrogen Program Office: Arlington, VA, USA, 2002.

92. Lehner, M.; Tichler, R.; Steinmüller, H.; Koppe, M. Power-to-Gas: Technology and Business Models; Springer: Berlin, Germany, 2014.

93. Ausfelder, F.; Beilmann, C.; Bertau, M.; Bräuninger, S.; Heinzel, A.; Hoer, R.; Koch, W.; Mahlendorf, F.; Metzelthin, A.; Peuckert, M.; et al. Energiespeicherung als Element einer sicheren Energieversorgung. Chem. Ing. Tech. 2015, 87, 17-89. [CrossRef]

94. Ueckerdt, F.; Luderer, G.; Müller-Hansen, F. Analyse des Klimaschutzpotentials der Nutzung von Erneuerbarem Wasserstoff und Methan; Abschlussbericht DVGW-Forschungsvorhaben, 2013.

95. Grigor'ev, S.; Grigor'ev, A.; Kuleshov, N.; Fateev, V.; Kuleshov, V. Combined heat and power (cogeneration) plant based on renewable energy sources and electrochemical hydrogen systems. Therm. Eng. 2015, 62, 81-87. [CrossRef]

96. Hydrogen-Based Energy Conversion MTSSF. SBC Energy Institute presentation, February 2014. Available online: http:/ / www.4is-cnmi.com/presentations/SBC-Energy-Institute_Hydrogen-based-energyconversion_FactBook-vf.pdf (accessed on 11 February 2017).

97. Installation Instructions for Registered Installers, Navien Stirling Engine M-CHP Installation Manual, NCM-1130HH; KD Navien Co. Ltd.: Souel, Korea, 2015.

98. RETScreen Software, version 4; CanmetENERGY: Ottawa, ON, Canada, 2017.

99. Catalogue of CHP Technologies USEPACHaPP, December 2008. Available online: http://www.epa.gov / chp/documents / catalog_chptech_full.pdf (accessed on 02 May 2014).

100. Maroufmashat, A.; Elkamel, A.; Fowler, M.; Sattari, S.; Roshandel, R.; Hajimiragha, A.; Walker, S.; Entchev, E. Modeling and optimization of a network of energy hubs to improve economic and emission considerations. Energy 2015, 93, 2546-2558. [CrossRef]

101. Maroufmashat, A.; Sattari, S.; Roshandel, R.; Fowler, M.; Elkamel, A. Multi-objective optimization for design and operation of distributed energy systems through the multi-energy hub network approach. Ind. Eng. Chem. Res. 2016, 55, 8950-8966. [CrossRef]

102. Sternberg, A.; Bardow, A. Life cycle assessment of power-to-gas: Syngas vs Methane. ACS Sustain. Chem. Eng. 2016, 4, 4156-4165. [CrossRef]

103. Argonne National Laboratories. The Greenhouse Gases re, and Energy Use in Transportation Model (2014). Available online: https:/ / greet.es.anl.gov/ (accessed on 2 May 2017).

104. Oliver, B. Canada as a Global Leader in Advanced Electrified Rail Technology, on Behalf of Hydrogenics, Executive Report. Available online: http:/ / www.ourcommons.ca/Content/Committee/421/FINA/Brief/ BR8404226/br-external/Tech-KOInc-e.pdf (accessed on 2 May 2017).

105. Brouillette, B. Extending Pickering Nuclear Generating Station Operations An Emissions and Economic Assessment for 2021 to 2024; Strategic policy economics: Ottawa, ON, Canada, 2015.

(C) 2017 by the authors. Licensee MDPI, Basel, Switzerland. This article is an open access article distributed under the terms and conditions of the Creative Commons Attribution (CC BY) license (http:/ / creativecommons.org/licenses/by/4.0/). 